Of the patients who had severe reactions to suxamethonium only 1 had received the drug previously. The possibility of sensitivity being acquired from other quaternary ammonium compounds has been suggested, ${ }^{14}$ and the high frequency of positive prick-tests to 'Cetrimonium' (ICI), a quaternary ammonium compound, in patients who reacted to suxamethonium in a French series ${ }^{10}$ is interesting.

The incidence of severe anaphylactoid reactions during anaesthesia is 1 in 10000 cases. Consequently, screening a large population for the antibody is unlikely to be rewarding or a cost-effective preventive manoeuvre. Further studies are also needed to determine the value of this assay in the diagnosis of anaphylactoid reactions during anaesthesia. However, administration of suxamethonium to subjects who have a positive reaction with the assay should be avoided. The occurrence of minor reactions in 2 patients (17 and 19) who had negative skin-tests, but significant uptakes of radioactive anti-IgE, suggests that the assay may add useful information to intradermal testing, that the mechanism of these reactions involves $\mathrm{IgE}$, that subsequent exposure to relaxants incriminated by intradermal testing is contraindicated, and that the cross-sensitivity between relaxants is likely to be a greater problem than previously believed. ${ }^{6}$

This work was funded by the National Health and Medical Research Council of Australia and the Harry Daly Foundation of the Faculty of Anaesthetists, Royal Australasian College of Surgeons.

Correspondence should be addressed to B. A. B. Kolling Institure of Medical Research, Royal North Shore Hospital, St Leonards, New South Wales 2065, Australia.

\section{IS CYTOMEGALOVIRUS INFECTION A MAJOR CAUSE OF T CELL ALTERATIONS AFTER (AUTOLOGOUS) BONE-MARROW TRANSPLANTATION?}

\author{
LEO F. VERDONCK GIJSBERT C. DE GAST \\ Department of Haematology, University Hospital Utrecht, \\ Netherlands
}

Summary Peripheral-blood $T$ cell subsets and functions were studied in 14 patients with malignancies treated with high-dose chemotherapy and radiotherapy followed by autologous bone-marrow transplantation (BMT). $8 \mathrm{CMV}$-positive patients (6 with latent infections and 2 with a primary infection) showed an inversion of the OKT4/OK T 8 ratio caused by an increase in $\mathrm{OKT} 8+\mathrm{T}$ cells and a decrease in OKT $4+\mathrm{T}$ cells. This was accompanied by a pronounced increase in the percentage of HLA-DR + T cells, and functionally by increased suppressor $T$ cell activity and decreased helper $T$ cell activity and $T$ cell proliferation. These alterations in $T$ cell subsets and functions were not observed in 6 patients who were kept CMV-negative by a deliberate transfusion policy. In the 6 patients helper $T$ cell activity and $T$ cell proliferation capacity recovered well after day 30 . Differences between the two groups were most striking 60 days after BMT. This study suggests that $\mathrm{CMV}$ infection, whether primary or secondary, is a major cause of $\mathrm{T}$ cell alterations after (autologous) BMT.

\section{Introduction}

PROFOUND combined immunological deficiency is found for at least 6 months after allogeneic bone-marrow transplantation (BMT). The resulting increased incidence of opportunistic infections ${ }^{1-4}$ seems mainly to result from

\section{REFERENCES}

1. Vervloet D, Afnaud A, Vellieux P, Kaplanski S, Charpin J. Anaphylactic reactions to muscle relaxants under general anaesthesia. F Allergy Clin Immunol 1979; 63: $348-53$.

2. Fisher MM. Reagınic antıbodies to drugs used in anaesthesia. Anesthestology 1980; 52: 318-20.

3. Lim M, Churchill-Davidson HC. Adverse effects of neuromuscular blockıng drugs. In Thornton JW, ed. Adverse reactions to anaesthetic drugs. Monographs in anaesthesiology, no 8. Amsterdam: Elsevier, 1981: 65-136.

4. Moneret-Vautrin DA, Laxenaire $M C$, Moeller R. Anaphylaxıs due to succinylcholine Clin Allergy 1981; 11: 175-83.

5. Fisher MM, Munro I. Life-threatening anaphylactoid reactions to muscle relaxants Anesth Analg (Cleve) 1983; 62: 559-64.

6. Stoetling RK. Allergic reactions during anaesthesia. Anesth Analg (Cleve) 1983; 62: $341-56$.

7 Youngman PR, Taylor $\mathrm{KM}, \mathrm{W}_{1} 1$ son JD. Anaphylactoid reactions to neuromuscular blocking agents a commonly undiagnosed condition? Lancet 1983; is: 597-99.

8. Scowen E. Committee on safety of medicine. Br 7 Anaesth 1978; 50: 170 .

9. Fisher MM, Baldo BA. Adverse reactions to alcuronium. An Australian disease? Med $f$ Aust 1983; 1: 630-32.

10. Vervloet D, Nizankowska E, Arnaud A, Senft $M$, Alazia $M$, Charpin J. Adverse reactions to suxamethonium and other muscle relaxants under general anaesthesia. Allergy Clm Immunol 1983; 71: 552-59.

11. Paton W. Histamine release by compounds of simple chemical structure. Pharmacol Rev 1957; 9: 269-301.

12. Editorial. Histamine and antihistamines in anaesthesia and surgery. Lancet 1981 ; 11 $74-75$.

13. Baldo BA, Fisher MM. Detection of serum IgE antibodies that react with alcuronium and tubocurarine after life-threatening reactions to muscle relaxant drugs. Anaesth Intensive Care 1983; 11: 194-97.

14. Baldo BA, Fisher MM Substituted ammonium tons as allergic determinants in drug allergy. Nature 1983; 306: $262-64$.

15. Baldo BA, Fisher MM. Anaphylaxıs to muscle relaxant drugs: cross-reactivity and molecular basıs of binding of IgE antibodies detected by radıommunoassay. Molecular Immunol 1983; 20: 1393-1400.

16. Fisher $M M$. The diagnosis of acute anaphylactoid reactions to anaesthetic drugs Anaesth Intenstve Care 1981; 9: 242-47.

17. Assem ESK, Frost PG, Levis RD. Anaphylactic-like reaction to suxamethonum Anaesthesia 1981; 36: 405-10.

18. Fisher MM, Chan MYC. Anaphylaxis to both decamethonium and suxamethonium Anaesth Intenszve Care 1982; 10: 153-55.

alterations of $T$ cell functions and defective $B$ cell maturation..$^{5-7}$ Although opportunistic infections are less frequent in syngeneic ${ }^{8}$ and autologous ${ }^{9,10} \mathrm{BMT}$, similar immunological alterations are found and thus seem to be independent of the type of graft or the presence of acute graft versus-host disease., ${ }^{7,112}$ The inversion of the OK T4/OKT8 ratio has been explained as being the result of a more rapid recovery of the OKT8 subset. ${ }^{7,13,14}$ We have studied T cell alterations in CMV-positive patients and CMV-negative patients after autologous BMT.

\section{Patients and Methods}

\section{Patients}

8 patients with a non-Hodgkin lymphoma (NHL) of high-grade malignancy and 3 patients with acute leukaemia (AL) were treated with cyclophosphamide $(120 \mathrm{mg} / \mathrm{kg})$ and total-body irradiation $(800$ $\mathrm{rad}) .3$ patients with a testicular carcinoma were treated with cyclophosphamide $\left(6000 \mathrm{mg} / \mathrm{m}^{2}\right)$ and etoposide $\left(1200 \mathrm{mg} / \mathrm{m}^{2}\right)$. Chemotherapy or radiotherapy was followed by autologous BMT. Details of the patients are summarised in table 1 .

A primary CMV infection, manifesting as interstitial pneumonia or haemorrhagic gastroenteritis, developed in patients 1 and 2 . In each case the source of infection was thrombocyte concentrates obtained from a relation who was CMV seropositive. Cultures from both patients were CMV positive. Serological studies of 6 patients with a latent $\mathrm{CMV}$ infection demonstrated reactivation or reinfection (a fourfold or greater titre rise) in only patients 3 and 5 and cultures became CMV positive in patient 3 . Prompted by the experience in the first 2 patients with a primary $C M V$ infection, we adopted a deliberate transfusion policy in the $6 \mathrm{CMV}$-negative patients. Filtered leucocyte-free erythrocytes and thrombocyte concentrates from CMV seronegative donors were used. No granulocyte concentrates were used. These patients remained negative for CMV by serology and culture during follow-up. A fever (without other symptoms or signs) developed 2 months after BMT in patient 13. Antibody titres to Epstein-Barr virus (EBV) became positive, indicating a primary EBV infection. 
TABLE I-PATIENT DATA

\begin{tabular}{|c|c|c|c|c|c|c|c|c|}
\hline $\begin{array}{l}\text { Patient } \\
\text { no }\end{array}$ & Diagnosis & Sex & $\begin{array}{c}\text { Age } \\
\text { (years) }\end{array}$ & Status at BMT & Response & $\begin{array}{c}\text { Duration } \\
\text { of CR } \\
\text { (months) }\end{array}$ & Cause of death & CMV status \\
\hline $\begin{array}{l}1 \\
2 \\
\end{array}$ & $\begin{array}{c}\text { NHL } \\
\text { Testis ca } \\
\end{array}$ & $\begin{array}{l}M \\
M\end{array}$ & $\begin{array}{l}53 \\
29 \\
\end{array}$ & $\begin{array}{l}\text { Drug resistant } \\
\text { Drug resistant }\end{array}$ & $\begin{array}{l}\mathrm{CR} \\
\mathrm{CR} \\
\end{array}$ & $\begin{array}{l}2 \\
8\end{array}$ & $\begin{array}{l}\text { CMV-IP } \\
\text { Relapse }\end{array}$ & $\begin{array}{l}\text { Primary } \\
\text { Primary }\end{array}$ \\
\hline $\begin{array}{l}3 \\
4 \\
5 \\
6 \\
7 \\
8\end{array}$ & $\begin{array}{l}\text { ALL } \\
\text { Testis ca } \\
\text { NHL } \\
\text { NHL } \\
\text { AML } \\
\text { NHL }\end{array}$ & $\begin{array}{l}M \\
M \\
M \\
M \\
F \\
M\end{array}$ & $\begin{array}{l}23 \\
25 \\
39 \\
15 \\
35 \\
38\end{array}$ & $\begin{array}{l}\text { 1st CR } \\
\text { Drug resistant } \\
\text { Primary, drug resistant } \\
\text { Primary, drug resistant } \\
\text { 2nd CR } \\
\text { PR }\end{array}$ & $\begin{array}{l}\text { CR } \\
\text { NR } \\
\text { CR } \\
\text { PR } \\
\text { CR } \\
\text { CR }\end{array}$ & $\begin{array}{l}14+ \\
\frac{4}{4} \\
\frac{3}{4+}\end{array}$ & $\begin{array}{l}\text {. } \\
\text { Progression } \\
\text { Relapse } \\
\text { Progression } \\
\text { Relapse } \\
\quad .\end{array}$ & $\begin{array}{l}\text { Latent } \\
\text { Latent } \\
\text { Latent } \\
\text { Latent } \\
\text { Latent } \\
\text { Latent }\end{array}$ \\
\hline $\begin{array}{r}9 \\
10 \\
11 \\
12 \\
13 \\
14\end{array}$ & $\begin{array}{l}\text { NHL } \\
\text { NHL } \\
\text { NHL } \\
\text { Testis ca } \\
\text { NHL } \\
\text { AML }\end{array}$ & $\begin{array}{l}M \\
F \\
M \\
M \\
M \\
M\end{array}$ & $\begin{array}{l}20 \\
35 \\
33 \\
24 \\
23 \\
28\end{array}$ & $\begin{array}{l}\text { 1st CR } \\
\text { PR } \\
\text { Primary, drug resistant } \\
\text { PR after 1st relapse } \\
\text { 1st CR } \\
\text { 1st CR }\end{array}$ & $\begin{array}{l}\mathrm{CR} \\
\mathrm{CR} \\
\mathrm{CR} \\
\mathrm{CR} \\
\mathrm{CR} \\
\mathrm{CR}\end{array}$ & $\begin{array}{c}18+ \\
15+ \\
5 \\
6+ \\
5+ \\
2+\end{array}$ & $\begin{array}{c}\cdots \\
\text { Relapse } \\
\ldots \\
\ldots \\
\ldots\end{array}$ & $\begin{array}{l}\text { Negative } \\
\text { Negative } \\
\text { Negative } \\
\text { Negative } \\
\text { Negative } \\
\text { Negative }\end{array}$ \\
\hline
\end{tabular}

NHL = non-Hodgkin lymphoma; AML = acute myeloid leukaemia; ALL = acute lymphoblastic leukaemia; testis ca = testicular carcinoma.

$\mathrm{CR}=$ complete remission; $\mathrm{PR}=$ partial remission; $\mathrm{NR}=$ no response; $\mathrm{IP}=$ interstitial pneumonia.

Identification of T cell subsets. - Lymphocyte subsets were studied before and at regular intervals after BMT in the mononuclear fraction of peripheral blood. T lymphocytes and $T$ cell subsets were determined by binding of the monoclonal antibodies OKT3 (pan T cell), OKT4 (comprising the helper/inducer $T$ cell subset), and OKT8 (comprising the suppressor/cytotoxic T cell subset) (Ortho Pharmaceutical Laboratories, Raritan, USA). HLA-DR antigen was determined on $T$ cells by the monoclonal antibody anti-human HLA-DR (clone L 243, Becton-Dickinson, Rutherford, USA).

Immunological function tests. -In-vitro cultures were performed as described elsewhere. ${ }^{15}$

Mitogen-induced proliferation.-The following mitogens were used in cultures containing $4 \times 10^{4}$ cells: phytohaemagglutinin PHA, $100 \mu \mathrm{g} / \mathrm{ml}$, HA 15, Wellcome), concanavalin-A (con-A, 75 ug/ml, A grade, Calbiochem), and pokeweed mitogen (PWM, $50 \mu \mathrm{g} / \mathrm{ml}$, Gibco Biocult). The counts per minute (cpm) in cultures stimulated with mitogens were compared with those from 2 simultaneous controls. The results are expressed as percentage of zontrol values.

Helper and suppressor $T$ cell activity. $-\mathrm{T}$ cell effector functions were determined as described previously ${ }^{7}$ with a slight modification. In brief, $T$ and non- $T$ cells from patients and controls were separated and mixtures of $2 \times 10^{4}$ non- $T$ cells and $2 \times 10^{4} \mathrm{~T}$ zells (irradiated) were stimulated with PWM. ${ }^{15}$ B cell differentiation was studied after 6 days of culture by counting the number of cytoplasmic Ig-positive cells which were mmunofluorescent. To assess helper T cell activity $2 \times 10^{4}$ normal 1on- $T$ cells were mixed with $2 \times 10^{4}$ patient $T$ cells (irradiated) and 0 assess suppressor $T$ cell activity, $1 \times 10^{4}$ patient $T$ cells (nonrradiated) were added to mixtures of normal non- $T$ and normal rradiated $T$ cells. Helper $T$ cell and suppressor $T$ cell activities were expressed as the percentage of a normal control by means of the ollowing formulas:

$$
\begin{aligned}
\% \mathrm{~T} \text { cell helper activity } & =\frac{\frac{\mathrm{Bn}+\mathrm{TpI}}{\mathrm{Bn}+\mathrm{TnI}} \times 100}{\% \mathrm{~T} \text { cell suppressor activity }=}\left[1-\frac{\mathrm{Bn}+\mathrm{TnI}+\mathrm{Tp}}{\mathrm{Bn}+\mathrm{TnI}}\right] \times 100
\end{aligned}
$$

$B=$ non $-T$ cell fraction; $T=T$ cell fraction; $I=$ irradiated; $p=$ patient; $1=$ normal control.

Normal $\mathrm{T}$ cells exhibited a suppressor activity between $0 \%$ and $50 \%$.

CMV infections were monitored by measurement of antibody itres in an enzyme-linked immunosorbent assay (ELISA) ${ }^{16}$ and by viral cultures (from urine, saliva, and buffy coat).

Statistical tests.-Differences between the CMV-positive and IMV-negative groups were evaluated by Student's $t$ test. p values ess than 0.05 were regarded as significant.

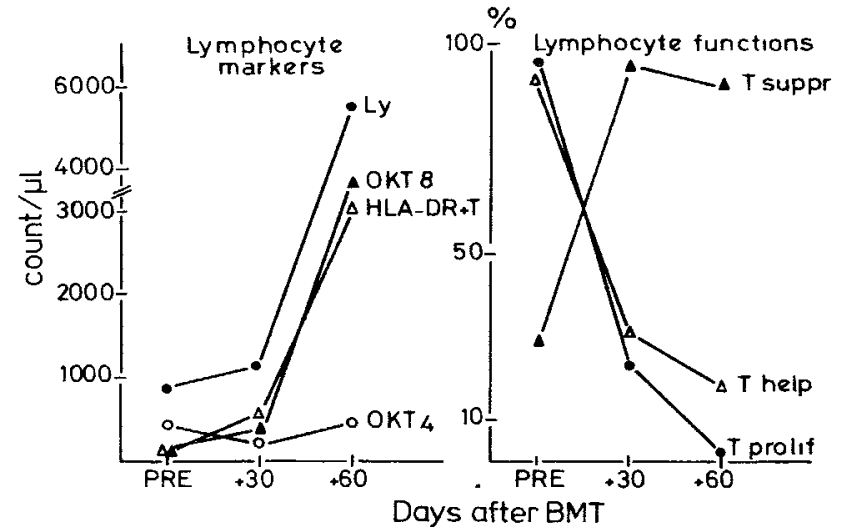

Fig 1-Primary CMV infection (2 patients).

$T$ cell alterations were accompanied or even preceded by high suppressor $T$ cell activity and very low helper $\mathrm{T}$ and proliferative $\mathrm{T}$ cell activity.

TABLE II-LYMPHOCYTE COUNT, OKT 4/OKT 8 RATIO AND PERCENTAGE HLA-DR + T CELLS IN RELATION TO CMV INFECTION

\begin{tabular}{|c|c|c|c|c|c|}
\hline- & $\begin{array}{l}\text { CMV } \\
\text { status }\end{array}$ & $\begin{array}{c}\text { Pre } \\
\text { BMT }\end{array}$ & $\begin{array}{l}+30 \\
\text { days }\end{array}$ & $\begin{array}{l}+60 \\
\text { days }\end{array}$ & $\begin{array}{c}+100 \\
\text { days }\end{array}$ \\
\hline $\begin{array}{l}\text { Lymphocyte count } \\
\text { (normal: } \\
1500-4000 \mu 1)\end{array}$ & $\begin{array}{l}\text { Negative } \\
\text { Positive }\end{array}$ & $\begin{array}{c}1735^{\star} \\
( \pm 111) \\
1249 \\
( \pm 157)\end{array}$ & $\begin{array}{c}1402 \\
( \pm 359) \\
1745 \\
( \pm 247)\end{array}$ & $\begin{array}{c}752 \\
( \pm 108) \\
1591 \\
( \pm 249)\end{array}$ & $\begin{array}{c}916 \\
( \pm 189) \\
1279 \\
( \pm 254)\end{array}$ \\
\hline $\begin{array}{l}\text { OKT4/OKT8 ratio } \\
\text { (normal: } 1 \cdot 5-2 \cdot 4 \text { ) }\end{array}$ & $\begin{array}{l}\text { Negative } \\
\text { Positive } \\
\text { tp value }\end{array}$ & $\begin{array}{c}1.7 \\
( \pm 0 \cdot 2) \\
0.9 \\
( \pm 0 \cdot 2) \\
<0.01\end{array}$ & $\begin{array}{c}1.5 \\
( \pm 0.3) \\
0.6 \\
( \pm 0.2) \\
<0.01\end{array}$ & $\begin{array}{c}1 \cdot 3 \\
( \pm 0 \cdot 1) \\
0 \cdot 3 \\
( \pm 0 \cdot 1) \\
<0 \cdot 01\end{array}$ & $\begin{array}{c}1 \cdot 2 \\
( \pm 0 \cdot 3) \\
0 \cdot 3 \\
( \pm 0 \cdot 2) \\
<0 \cdot 01\end{array}$ \\
\hline $\begin{array}{l}\% \text { HLA-DR T cells } \\
\text { (normal: }<5 \%)\end{array}$ & $\begin{array}{l}\text { Negative } \\
\text { Positive } \\
\text { †p value }\end{array}$ & $\begin{array}{c}8 \\
( \pm 4) \\
30 \\
( \pm 8) \\
<0.05\end{array}$ & $\begin{array}{c}20 \\
( \pm 6) \\
63 \\
( \pm 5) \\
<0 \cdot 01\end{array}$ & $\begin{array}{c}17 \\
( \pm 4) \\
48 \\
( \pm 7) \\
<0 \cdot 01\end{array}$ & $\begin{array}{c}11 \\
( \pm 3) \\
52 \\
( \pm 14) \\
\text { NS }\end{array}$ \\
\hline
\end{tabular}
(MEAN \pm SEM)

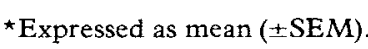

†Student's $t$ test.

NS = not significant

\section{Results}

\section{Lymphocyte Subsets after BMT}

60 days after BMT the 2 patients with a primary CMV infection (fig 1) showed a pronounced increase in lymphocytes, which were nearly all activated T cells (HLA$\mathrm{DR}+$ ) with the suppressor/cytotoxic phenotype (OKT8+). On day 60 the OKT $4 / O K T 8$ ratio in these 2 patients was very 


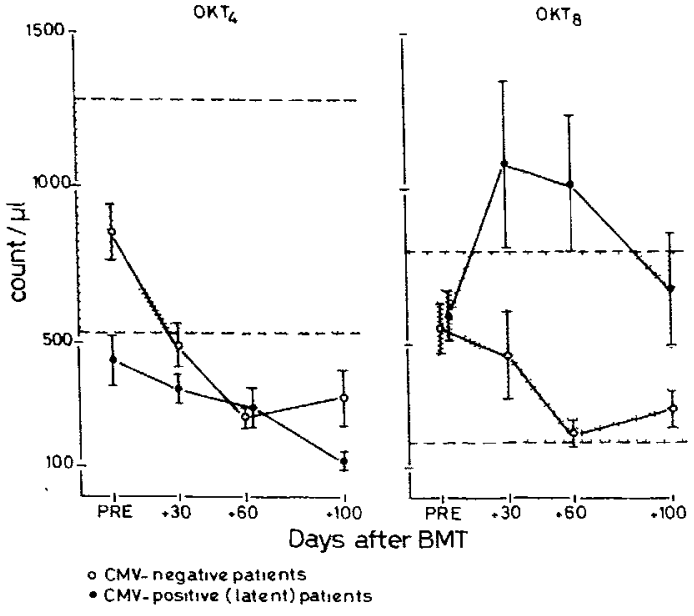

Fig 2-Counts of T cells of helper/inducer phenotype (OKT4 + ) and of suppressor/cytotoxic phenotype $(\mathrm{OKT} 8+)$ in relation to CMV infection after BMT.

Stippled bands indicate normal ranges.

low $(0.02$ and $0 \cdot 3)$. The $6 \mathrm{CMV}$-positive patients with a latent infection showed a nearly normal lymphocyte count after BMT (table II). This was mainly the result of an increase in the number of OKT8 + T cells, and a concomitant decrease in OKT4+ T cells (fig 2). This resulted in an inverted OKT4/OKT8 ratio. Most $T$ cells were HLA-DR + too (table II).

In contrast, the 6 CMV-negative patients were lymphopenic (table II). OKT4+ and OKT $8+\mathrm{T}$ cell numbers were decreased (fig 2), and the OKT4/OKT8 ratio was not inverted (table II). In $1 \mathrm{CMV}$-negative patient the OKT4/OK T 8 ratio was inverted at day 60 and day $100(0 \cdot 2)$, probably as a result of a primary EBV infection. HLA-DR + $T$ cells numbers were only slightly increased in the CMVnegative patients (table II).

The CMV-positive patients with a latent infection had already an inverted OKT4/OK T8 ratio and an increased number of HLA-DR $+\mathrm{T}$ cells before BMT. Difference in OKT4/OKT8 ratio and percentage HLA-DR + T cells between the CMV-positive and CMV-negative group were significant, both before and after BMT.

\section{Lymphocyte Function after BMT}

In 2 patients with a primary CMV infection there was a pronounced increase in suppressor $\mathrm{T}$ cell activity and very low helper and proliferative T cell capacity after BMT (fig 1). The 6 CMV-positive patients showed similar $T$ cell functions-ie, pronounced increase in suppressor $\mathrm{T}$ cell activity and very low helper $T$ cell and $T$ cell proliferative capacity (fig 3 ). Increased suppressor $T$ cell activity was already present in $4 / 6$ patients before BMT. In contrast, the 6

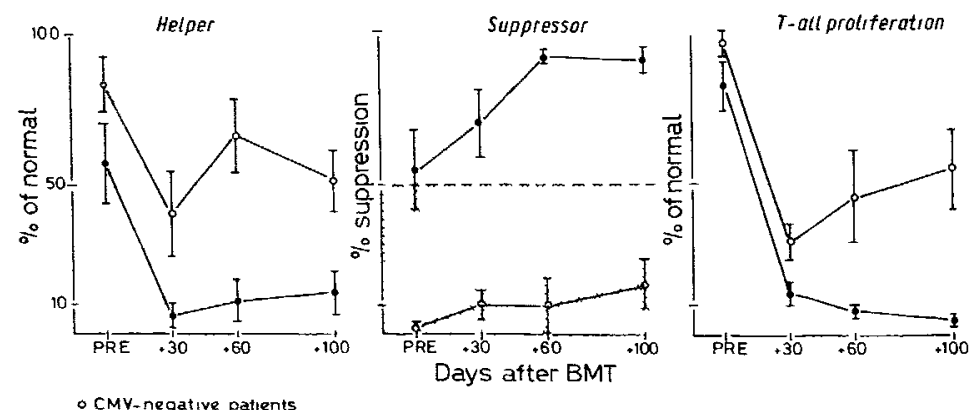

- CMV-negative patients
- CMV-positive (latent) patients

Fig 3-Lymphocyte function in relation to CMV infection.

Stıppled bands indicate normal range.
CMV-negative patients showed a normal suppressor $\mathrm{T}$ cell activity before and after BMT (fig 3), except the patient with the primary EBV infection (50\% suppression at day 60 and $89 \%$ at day 100). Differences between the two groups are significant before and after BMT if the patient with EBV is excluded. Helper T cell activity and $\mathrm{T}$ cell proliferation were low at day 30, but gradually recovered after that period, in contrast to the results in CMV-positive patients (fig 3). Differences between the groups were significant at day 30 and day 60 and for day 100 for $T$ cell proliferation capacity.

\section{Discussion}

A preponderance of suppressor/cytotoxic $\mathrm{T}$ cells $(\mathrm{OKT} 8+)$, an inversion of the OK T4/OK T 8 ratio, ${ }^{11,13,17,18}$ and the increase of HLA-DR $+\mathrm{T}$ cells ${ }^{18,19}$ have been reported after allogeneic BMT. The inversion was also found after autologous ${ }^{11,20}$ and syngeneic ${ }^{11}$ BMT. The preponderance of the $\mathrm{OKT} 8+$ subset is generally ascribed to a faster repopulation and maturation. ${ }^{7,13,14}$ Most $\mathrm{T}$ cells in normal bone-marrow are OKT $8+,{ }^{21}$ and the preponderance of OKT $8+T$ cells may also be the result of a rapid increase in numbers of already mature $T$ cells.

In normal individuals herpes virus infections, especially CMV and EBV are accompanied by lymphocytosis and a marked increase in OKT $8+$ and HLA-DR + T cells. ${ }^{22-24}$ In this study a lymphocytosis with a high number of OKT $8+$ and HLA-DR + $T$ cells was found in 2 patients with a primary $C M V$ infection after autologous $B M T$. The CMV. positive (latent) patients also showed a pronounced inversion of the OKT4/OKT8 ratio, which was the result of a low number of OKT4 + cells and a normal to increased number of OKT8 + T cells. The percentage of HLA-DR + T cells was increased too. The $\mathrm{CMV}$-negative patients displayed no inversion of the OKT4/OKT8 ratio. Both the number of $\mathrm{OKT} 4+\mathrm{T}$ cells and the number of OKT $8+\mathrm{T}$ cells were decreased. Only $1 \mathrm{CMV}$-negative patient showed an inversion of the OKT4/OKT8 ratio after BMT, probably as a result of a primary EBV infection.

The functional tests accorded with the alterations in $\mathrm{T}$ cell subsets. Patients with a CMV infection (both latent and primary) displayed a low $\mathrm{T}$ cell proliferation and helper $\mathrm{T}$ cell function and a markedly increased (non-specific) suppressor $T$ cell function. These findings accord with other studies in BMT patients ${ }^{3,5-7}$ and resemble findings in normal individuals with a $\mathrm{CMV}$ infection. ${ }^{25}$ The CMV-negative patients in contrast, demonstrated a rather good recovery of helper $T$ cells and $T$ cell proliferative capacity after day 30 and a normal suppressor $T$ cell function. Differences between the CMV-positive (latent infection) and the CMV-negative patients were significant in this small study.

Since both patient groups had received similar treatment with high-dose chemotherapy and/or radiotherapy before autologous BMT and since both groups differed solely in the presence or absence of $\mathrm{CMV}$ antibodies before $\mathrm{BMT}$, it is unlikely that the observed $T$ cell changes were the cause of the (secondary) CMV infection. That they were indeed the result of the CMV infection is supported by the data in the 2 patients with a primary infection, who showed a pronounced increase of OKT $8+$ and HLA-DR + T cells only at day 60 and not at day 30 after BMT. In the CMV-positive patients the immunodeficiency caused by the high-dose chemotherapy and/or radiotherapy probably induced reactivation of the CMV infection, and alterations in $\mathrm{T}$ cell subsets resulted. None of the $6 \mathrm{CMV}$-positive patients showed clinical symptoms of CMV infection after $\mathrm{BMT}$ and reactivation demonstrated by a rise in titre and/or excretion of CMV was 
found in only 2 patients. So $T$ cell alterations may be the first sign of reactivation of $C M V$.

We conclude that a preponderance of OKT $8+\mathrm{T}$ cells after BMT is not merely the result of a faster repopulation by OKT $8+\mathrm{T}$ cells. In autologous BMT, CMV infections (and to a lesser degree other viral infections such as EBV infection) seem to be an important cause of immunological changes and of the preponderance of OKT $8+T$ cells with accompanying high suppressor $\mathrm{T}$ cell activity. CMV infection is probably important in allogeneic BMT too, although graft-versus-host disease also results in immunological changes. Since morbidity and mortality associated with primary $\mathrm{CMV}$ infections are high, a deliberate transfusion policy should be adopted in CMV-negative patients. The high suppressor $\mathrm{T}$ cell activity with an impairment of helper $T$ cell and $T$ cell proliferative capacity in patients with a latent CMV infection, probably increases the frequency of opportunistic infections. Effective measures to prevent a primary CMV infection or the reactivation of a latent $\mathrm{CMV}$ infection (possibly by immune plasma) may help to reduce the frequency of these complications.

We thank Joke van der Linden, Hans van Heugten, Henny Kreeft, and Annemarie Smulders for their technical assistance; J. Middeldorp and T. H. The for performing the CMV antibody tests; and E. J. E. G. Bast for valuable discussion of the results. This study was supported by a grant from the Stichting Koningin Wilhelmina Fonds, Nederlandse Organisatie voor de Kankerbestrijding (UUKC-Haem 81)

Correspondence should be addressed to L. F. V., Department of Haematology, University Hospital Utrecht Catharijnesingel 101, PB 16250, $3500 \mathrm{cg}$ Utrecht, The Netherlands.

\section{REFERENCES}

Thomas ED, Buckner CD, Banaji $M$, Clift RA, Fefer A, Flournoy $N$, Goodell BW, Hickman RO, Lerner KG, Neiman PE, Sale GE, Sanders JE, Singer J, Stevens $M$, Storb R, Weiden PL. One hundred patients with acute leukaemia treated by chemotherapy, total body irradation, and allogeneic marrow transplantation. Blood 1977; 49: $511-33$.

2. Neiman PE, Reeves R, Ray G, Flournoy N, Lerner KG, Sales GE, Thomas ED. A prospective analysis of interstitial pneumonia and opportunistic viral infection among recipients of allogeneic bone marrow graft. F Infect Dis 1977; 136: 754-67.

3. Gale RP, Opelz G, Mickey MR, Graze PR, Saxon A for the UCLA Bone Marrow Transplant Team, Immunodeficiency following allogeneic bone marrow transplantation. Transplant Proc 1978; 10: 233-37.

4. Winston DJ, Gale RP, Meyer DV, Young LS. Infectious complications of human bone marrow transplantation. Medicze 1979; 58: $1-31$.

5. Lum LG, Seigneuret MC, Storb $R$, Witherspoon RP, Thomas ED In vitro regulation of immunoglobulin synthesis after marrow transplantation. I. T-cell and B-cell deficiencies in patıents with and without chronic graft-versus-host disease. Blood 1981; 58: $431-39$.

6. Korsmeyer SJ, Elfenbein GJ, Goldman CK, Marschall SL, Santos GW, Waldmann TA. B cell, helper $T$ cell, and suppressor $T$ cell abnormalities contribute to disordered immunoglobulin synthesis in patients following bone marrow transplantation. Transplantation 1982; 33: 184-90.

7. Witherspoon RP, Lum LG, Storb R, Thomas ED. In vitro regulation of immunoglobulin synthesis after human marrow transplanation. II. Deficient $T$ and non-T lymphocyte function within 3-4 months of allogeneic, syngeneic, or autologous marrow grafting for haematologic malignancy. Blood 1982; 59: 844-50,

8. Appelbaum FR, Meyers JD, Fefer A, Flournoy N, Cheever MA, Greenberg PD, Hackman R, Thomas ED. Nonbacterial nonfungal pneumonia following marrow transplantation in 100 identical twins. Transplantation 1982; 33: 265-68.

9. Buckner CD, Stewart P, Clift RA, Fefer A, Neıman PE, Singer J, Storb R, Thomas ED. Treatment of blastic transformation of chronic granulocytic leukemia by chemotherapy, total body irradiation and infusion of cryopreserved autologous marrow. Exp Hematol 1978; 6: 96-109.

10. Dicke KA, Spitzer G, Peters I, McCredie KB, Zander A, Verma DS, Vellekoop L, Hester J. Autologous bone marrow transplantation in relapsed adult acute leukaemia. Lancet $1979 ; 1$ : 514-17.

11. Atkinson K, Hansen JA, Storb R, Goehle S, Goldstein G, Thomas ED. T-cell subpopulations identified by monoclonal antibodies after human marrow transplantation. I. Helper-1nducer and cytotoxic-suppressor subsets. Blood 1982; 59: $1292-98$.

2 Witherspoon RP, Kopecky K, Storb R, Flournoy N, Sullivan KM, Sosa R, Deeg HJ, Ochs HD, Cheever MA, Fefer A, Thomas ED. Immunological recovery in 48 patients following syngeneic marrow transplantation for hematological malignancy. Transplantation 1982; 33: 143-49.

13. Friedrich W, O'Reilly RJ, Koziner B, Gebhard DF Jr, Good RA, Evans RL. T-lymphocyte reconstitution in recipients of bone marrow transplants with and without GVHD: Imbalances of T-cell subpopulations having unique regulatory and cognutive functions. Blood 1982; 59: 696-701.

14 Lum LG, Orcutt-Thordarson N, Seigneuret $M C$, Storb R. The regulations of Ig synthesis after marrow transplantation. IV. T4 and $\mathrm{T} 8$ subset function in patients with chronic graft-vs-host disease. 7 Immunol 1982; 129: 113-19.
TYPING SCHEME FOR CLOSTRIDIUM DIFFICILE: ITS APPLICATION IN CLINICAL AND EPIDEMIOLOGICAL STUDIES
SOAD TABAQCHALI
SHEILA O'FARRELI
DIANE HOLLAND
ROBERT SILMAN Departments of Medical Microbiology and Reproductive Physiology,
St Bartholomew's Hospital, London EC1

Summary Epidemiological studies of Clostridium difficile diarrhoeal disease have been hindered by the lack of a typing scheme for this organism. A typing method based on the incorporation of sulphur-35labelled methionine into cellular proteins and their separation by sodium dodecylsulphate/polyacrylamide gel electrophoresis showed clear pattern differences between strains, and nine distinct groups within the $C$ difficile species were established. $98 \%$ of 250 clinical strains derived from four hospitals were typable. Group X was the commonest group and was associated with outbreaks of pseudomembranous colitis and antibiotic-associated colitis in two hospitals. Groups A-D were isolated predominantly from mothers and newborn infants. In outbreaks of antibiotic-associated colitis in oncology and orthopaedic wards the same strains, group X and group $\mathrm{E}$, respectively, were isolated from patients and their environment, providing strong evidence of crossinfection between patients and of hospital acquisition of C difficile.

\section{Introduction}

Clostridium difficile is well known to be the primary cause of pseudomembranous colitis and antibiotic-associated colitis. ${ }^{1-5}$ There are several reports of clusters of such cases in hospitals. ${ }^{6-11}$ However, the important questions of whether cross-infection occurs and whether patients acquire the organism from the hospital environment are still not answered, because a suitable system for typing this organism is lacking.

A bacteriophage typing scheme is being developed by Sell et al, ${ }^{12}$ and Wüst et al ${ }^{13}$ have applied various existing methods,

$$
\text { L. F. VERDONCK AND OTHERS: REFERENCES-continued }
$$

15. De Gast GC, Platts-Mills TAE. Functional studies on lymphocytes in adult human bone marrow. I. Immunoglobulin production in vitro after fractionation on a sucrose gradient and T/non-T cell separation. F Immunol 1979; 122: 280-84.

16. Middeldorp JM. An ELISA-Technique for the detection of antibodies against early (EA) and late (LA) cytomegalovirus antigens. International workshop on herpes viruses. Bolognia: Escu lapio Publishing, 1981. 116.

17. De Bruin HG, Astald A, Leupers $T$, van de Griend R], Dooren LJ, Schellekens PTA, Tanke HJ, Roos $M$, Vossen JM. T lymphocyte characteristics in bone marrowtransplanted patients. II. Analysis with monoclonal antibodies. 7 Immunol 1981; 127: 244-5I.

18. Fox R, McMillan R, Spruce W, Tani P, Mason D and the Scripps Clinic Bone Marrow Transplantation Team. Analysis of $T$ lymphocytes after bone marrow transplantation using monoclonal antibodies. Blood $1982 ; 60 ; 579-82$.

19. Schroff RW, Gale RP, Fahey JL. Regeneration of T cell subpopulations after bone marrow transplantation: cytomegalovirus infection and lymphoid subset imbalance. f Immunol 1982; 129: 1926-30.

20. Linch DC, Knott LJ, Thomas RM, Harper P, Goldstone AH, Davis EG, Levinsk1 RJ. $T$ Cell regeneration after allogeneic and autologous bone marrow transplantation. Br f Haematol 1983; 53: 451-58

21. Janossy G, Tidman N, Papageorgiou ES, Kung PC, Goldstein G. Distribution of $T$ lymphocyte subsets in the human bone marrow and thymus: An analysis with monoclonal, antibodies. F Immunol 1981; 126: 1608-13.

22. Carney WP, Rubin RH, Hoffman RA, Hansen WP, Healy K, Kirsch MS. Analysis of T lymphocyte subsets in cytomegalovirus mononucleosis. F Immunol 1981; 126: $2114-16$

23. Reinharz EL, O'Brien C, Rosenthal P, Schlossman SF. The cellular basis for viralinduced immunodeficiency: Analysis by monoclonal antibodies $7 \mathrm{Immunol} 1980$; 125: $1269-74$

24. De Waele $M$, Thetlemans C, van Camp BKG. Characterization of immunoregularity $T$ cells in EBV-induced infections mononucleosis by monoclonal antibodies. $N$ Engl 7 Med 1981; 304: 460-62.

25. Rinaldo DR, Carney WP, Richter BS, Black PH, Hirsch MS. Mechanisms of immunosuppression in cytomegalovirus mononucleosss. F Infect Dis 1980; 141: $488-95$ 